\title{
Oil dependence, quality of political institutions and economic growth: A panel VAR approach*
}

\author{
Nikolaos Antonakakis ${ }^{\dagger \ddagger}$, Juncal Cunado ${ }^{\S}$, George Filis ${ }^{\Uparrow}$, and Fernando Perez de Gracia ${ }^{\S}$ \\ ${ }^{\dagger}$ Corresponding author. Department of Business and Management, Webster Vienna Private University, \\ Praterstrasse 23, 1020, Vienna, Austria. Tel: +43-1-2699293-4373. Email: \\ nikolaos.antonakakis@webster.ac.at \\ ${ }^{\ddagger}$ Economics and Finance Subject Group, University of Portsmouth, Portsmouth Business School, \\ Portland Street, Portsmouth, PO1 3DE, United Kingdom. Tel: +44 (0)23 9284 4261. Email: \\ nikolaos.antonakakis@port.ac.uk \\ $\S$ Universidad de Navarra, Facultad de Económicas y Empresariales, Departamento de \\ Economía.Campus Universitario, 31080,Pamplona,Spain.Email: jcunado@unav.es, fgracia@unav.es \\ `Bournemouth University, Department of Accounting, Finance and Economics, Executive Business \\ Centre, 89 Holdenhurst Road, BH8 8EB, Bournemouth, UK. Email: gfilis@bournemouth.ac.uk
}

June 21, 2017

\begin{abstract}
This paper examines the resource curse hypothesis both within and between countries of different democratic footprint, based on a dynamic model that properly accounts for endogeneity issues. To achieve that, we apply a panel Vector Auto-Regressive (PVAR) approach along with panel impulse response functions to data on oil dependence variables, economic growth and several political institutional variables in 76 countries classified by different income groupings and level of development, over the period 1980-2012. Our results suggest that controlling for the quality of political institutions, and in particular the constraints to the executives, is important in rendering the resource curse hypothesis significant. Doing so, the resource curse hypothesis is documented mainly for developing economies and mediumhigh income countries. Specifically, when economies from the aforementioned groups are characterised by weak quality of political institutions, then oil dependence is not growthenhancing.
\end{abstract}

Keywords: Resource curse, Oil dependence, Economic growth, Institutions, Panel VAR

JEL codes: C33, O47, Q32, Q33

\footnotetext{
*Juncal Cunado and Fernando Perez de Gracia acknowledge financial support from the Spanish Ministry of Economics and Competitiveness through project ECO-2014-55496R. George Filis acknowledges financial support from the European Union's Horizon 2020 research and innovation programme, which has funded him under the Marie Sklodowska-Curie grant agreement No 658494.
} 


\section{Introduction}

In their 1995 influential study titled "Natural resource abundance and economic growth", Sachs and Warner started a well-known line of research focusing on natural resources. They obtained a negative conditional relationship between economic growth and resource dependence using a cross section of international data, in line with the resource curse hypothesis. More specifically, they report that economies with abundant natural resources tend to experience lower economic growth compared to economies with scarce natural resources. Sachs and Warner $(1999,2001)$, Gylfason et al. (1999) and Rodriguez and Sachs (1999), among many others, also find a negative relationship between growth and resource abundance or dependence. ${ }^{1}$ However, the evidence in favour of the resource curse hypothesis is by no means conclusive (see, for example, Raddatz, 2007; Brunnschweiler and Bulte, 2008; Alexeev and Conrad, 2009; van der Ploeg and Poelhekke, 2010, among others). ${ }^{2}$ Alexeev and Conrad (2009), for example, demonstrate that high endowments of oil have a positive effect on per capita Gross Domestic Product (GDP), contradicting most of the empirical literature on the resource curse, while Brunnschweiler and Bulte (2008) find that resource dependence does not negatively affect growth and they define the resource curse as a red herring. However, van der Ploeg and Poelhekke (2010) challenge these results explaining that ignoring the volatility channel may lead to conclude that there is no resource curse. These authors find that while resource exports boosts growth in stable countries, they make especially volatile economies even more volatile, worsening growth opportunities in these countries.

In this study we re-examine the resource curse hypothesis in an attempt to shed more light into that field. The resource curse hypothesis literature reveals the following empirical regularities.

First, natural resource abundance is associated with various negative development outcomes (Sachs and Warner, 1995, 1999, 2001; Brückner, 2010), although the opposite evidence is still present (Alexeev and Conrad, 2009).

Second, existing explanations for the resource curse do not adequately account for the role of social forces or external political and economic environments in shaping development outcomes in resource abundant countries, nor for the fact that, while most resource abundant countries have performed poorly in developmental terms (i.e., the cases of Angola and Congo, rich in oil, or the group of OPEC countries) a few have done quite well (i.e., Norway).

\footnotetext{
${ }^{1}$ Previously, Gelb (1988) and Auty (2002) also documented this relationship.

${ }^{2}$ See, for example, Frankel (2010) and van der Ploeg (2011) for recent surveys.
} 
Third, recommendations for overcoming the resource curse have not generally taken into account the issue of political feasibility. More generally, it is argued that the basic problem with the literature is that researchers have been too reductionist they have tended to explain development performance solely in terms of the size and nature of countries' natural resource endowments. Nevertheless, a consensus is emerging that various political and social variables mediate the relationship between natural resource wealth and development outcomes (i.e., Isham et al., 2005; Mehlum et al., 2006a,b; Andersen and Aslaksen, 2008; Bhattacharyya and Hodler, 2010; Bjorvatn et al., 2012; Collier and Goderis, 2012; El Anshasy and Katsaiti, 2013). Even more, most of the studies have not fully addressed the issue of endogeneity and reverse causality between the variables of interest (Collier and Goderis, 2012). In this paper, we address all the above issues when analyzing the resource curse hypothesis. ${ }^{3}$

Thus, more specifically, the objective of this paper is to re-examine the dynamic links of the resource curse hypothesis both within and between countries of different democratic footprint. To achieve this, we apply a panel Vector Auto-Regressive (PVAR) approach along with panel impulse response functions to data on oil dependence (approximated by oil rents as a percentage of GDP, oil share as a percentage of GDP and oil revenue per capita) $)^{4,5}$, economic growth and several political institutional variables (i.e., polity IV index and its sub-indices and the political rights index), together with additional control variables. We consider 76 countries classified by different income groupings, level of development, as well as, their level of democracy over the period 1980-2012.

Two are the main contributions of the paper to previous existing economic literature. First, as far as the methodology is concerned, instead of using previous methodological approaches such as cross-section (Sachs and Warner, 1995, and many others), panel data (Bhattacharyya and Hodler, 2010; Boyce and Emery, 2011; Cavalcanti et al., 2011; Bjorvatn et al., 2012), panel error correction models (Collier and Goderis, 2012) or time-varying cointegration (Apergis and Payne, 2014) models, in this paper we estimate different panel VAR models. To our knowledge, this is the first paper that adopts a panel VAR approach and panel impulse response analysis to study the dynamic impact among oil dependence, the quality of political institutions, and

\footnotetext{
${ }^{3}$ In addition, related literature also considers the called "dutch disease", where the resource exports increase exchange rates and reduce the competitiveness of other domestic exporting sectors (i.e., Sachs and Warner, 1995; Gylfason et al., 1999; Sala-i Martin and Subramanian, 2013), nevertheless this falls outside the scope of this paper.

${ }^{4}$ Brückner (2010) shows that the negative relationship between resource dependence and economic growth is larger when resource dependence is calculated using a real measure of the share of natural resource exports in GNP adjusted for cross-country differences in the prices on non-tradables.

${ }^{5}$ We concentrate on oil dependence, given that oil is one of the most consumed and tradable natural resources IEA (2015). In addition, as suggested by Ross (2001), oil resources have antidemocratic properties.
} 
economic growth by taking into account the endogeneity of these variables, as well as controlling for commonly used variables in the endogenous economic growth theory.

The advantages of using a panel VAR methodology relative to methods previously discussed so as to examine the oil-based resource curse hypothesis are several. First, and in contrast to cross-country, panel data models allow us to control for unobservable time-invariant country characteristics, reducing concerns of omitted variable bias. Second, time fixed effects can also be added to account for any global (macroeconomic) shocks that may affect all countries in the same way. Third, the inclusion of lags of the variables helps to analyze the dynamic relationship between the different variables. Thus, impulse response functions based on PVARs can account for any delayed effects on and of the variables under consideration and thus determine whether the effects between the variables of interest are short-lived, long-lived or both. Such dynamic effects would not have been captured by panel regressions. Fourth, and most importantly, PVARs are explicitly designed to address the endogeneity problem, which is one of the most serious challenges of the empirical research on the resource curse hypothesis, by treating all variables as potentially endogenous. ${ }^{6}$ Last but not least, PVARs can be effectively employed with relative short-time series due to the efficiency gained from the cross-sectional dimension.

Our second contribution concerns the variables that are employed in this study. More specifically, we include three key variables, namely, oil dependence (proxied by three alternative indicators discussed in detail in the Section 2.1.), economic growth and institutional quality, together with other commonly used control variables that can potentially affect economic growth (i.e., labor force participation, gross fixed capital formation, foreign direct investment and openness). The inclusion of all these variables, together with their interactions (please see Section 2.1. for details), will allow us to account for the interdependencies among the quality of political institutions, economic growth and oil dependence. In order to better characterize the relationship between these variables, we also estimate the PVAR for different sub-groups of countries based on different characteristics, such as, income level or developing stage, so as to check whether the impact of institutional quality and oil dependence variables on economic growth potentially differs among each of these sub-groups of countries.

\footnotetext{
${ }^{6}$ The endogeneity problem in cross-country and panel data models has been previously addressed by the inclusion of different instrumental variables (Alexeev and Conrad, 2009; Cotet and Tsui, 2013), and by estimating the model using 2 or 3 Step Least Squares models (Brunnschweiler and Bulte, 2008; Busse and Gröning, 2013), Generalized Method of Moments (Lederman and Maloney, 2003; Maloney and Lederman, 2008) or Arellano-Bond Generalized Method of Moments (Yaduma et al., 2013). The difficulty in measuring good instruments of the variables included in these types of studies, such as oil dependence and quality of institutions, better justifies the use of panel VAR models, which help to alleviate the endogeneity problem by treating all variables as potentially endogenous.
} 
Of course, the impact of the quality of the institutions and democracy on economic growth has also been documented in many papers (Barro, 1999; Acemoglu et al., 2001, 2002; Papyrakis and Gerlagh, 2004; Epstein et al., 2006; Glaeser et al., 2007; Acemoglu et al., 2008; Papaioannou and Siourounis, 2008). Furthermore, the interaction between natural resources and economic growth, taking into account the role of institutions has been also previously studied by Isham et al. (2005), Mehlum et al. (2006a,b), Hodler (2006), Andersen and Aslaksen (2008), Bhattacharyya and Hodler (2010), Bjorvatn et al. (2012), Brückner et al. (2012), Collier and Goderis (2012) and El Anshasy and Katsaiti (2013), among many others.

Isham et al. (2005), for example, find that not only institutional quality has a significant effect on economic growth, but it is also determined by the resource abundance of each of the countries. Papyrakis and Gerlagh (2004) examine the impact of natural resource abundance on economic growth considering alternative transmission channels (corruption, investment, openness, terms of trade and schooling). Despite the negative relationship between natural resource abundance and economic growth, when these transmission channels are included, they obtain a positive the relationship between natural resources and economic growth. Hodler (2006), on the other hand, develop a model in which natural resources cause fighting activities between rivalling groups, while fighting reduces productive activities and weakens property rights, and thus, production activities. According to this author, apart from the natural resources' direct positive income effect, natural resources have an indirect effect on income through property rights, which depends on how fractionalized a country is. In addition, Mehlum et al. (2006a,b) use the same dataset as Sachs and Warner (1995), including an interaction effect between quality of institutions and resource dependence, and obtain that institutional quality is the key to understand the resource curse. They maintain that when institutions are bad, resource dependence is a curse, while it is a blessing when institutions are good. Furthermore, Andersen and Aslaksen (2008) analyze how public income shocks from natural resources have different long run economic effects dependent on constitutional designs. Using data from 90 economies divided into democratic and nondemocratic countries, they find that the form of government matters more than the democratic rule. In a recent study, Bhattacharyya and Hodler (2010) also analyse both theoretically and empirically whether and how the quality of the democratic institutions affects the relationship between natural resources and corruption. They confirm that the relationship between resource rents and corruption also depends on the quality of institutions.

Despite that there are some studies that have considered the quality of institutions in the link between resource dependence or abundance and economic growth, none of these studies have 
considered the effects of the constraints to the executives. This is rather important as there are cases where countries are autocratic, yet with strong constraints to the executive, which reduces the powers of the autocrat and thus, these economies may be closer to be democracies. An example of such country is Indonesia, where during the mid-60s Suharto overruled Sukarno with coups d'état, yet he was committed to maintain the property rights and investments of the business sector. During Suhartos era the country experienced significant growth with heavy investments in public goods and numerous reforms in the banking sector, as well as, in import trade monopolies (Hadiz and Robison, 2005). This is one of the key innovations of the paper, as it is the first study to examine the effects of these constraints in the context of the natural resource hypothesis.

The results of our empirical analysis, which remain sound to several robustness checks, reveal the following empirical regularities. A positive relationship between resource dependence and economic growth is documented for the overall sample. Put differently, the resource curse hypothesis is not present in the above case. However, controlling for the quality of political institutions, and more importantly the constraints to the executives, is important in rendering the resource curse hypothesis significant. Doing so, we find evidence of the resource curse hypothesis, mainly for developing economies and medium-high income countries. Specifically, when economies from the aforementioned groups are characterised by weak quality of political institutions, then oil dependence is not growth-enhancing.

The remainder of the paper is structured as follows. Section 2 presents the PVAR methodology and the data set. Empirical results based on alternative estimations are presented in Section 3. Finally, Section 4 concludes.

\section{Data set and methodology}

\subsection{Data set}

We consider an unbalanced panel of annual data from 76 countries that covers the period 19802012. In total we have 1471 country-year observations. The countries included in our dataset are listed in Table 1. Table 1 also divides our sample countries into the following subgroups that we also examine below: developed and developing and different income groups. The variables used in this paper are obtained from the World Bank, International Monetary Fund (IMF), US Energy Information Administration (EIA), Polity IV project and Freedom House (see Table 2 for a detailed description of our dataset and their sources). 
[Insert Table 1 about here]

[Insert Table 2 about here]

Following previous empirical related studies on natural resources that also use panel models (see, for example, Bhattacharyya and Hodler, 2010; Boyce and Emery, 2011; Cavalcanti et al., 2011; Bjorvatn et al., 2012, among others), we propose different specifications of PVAR models. We collect the following data:

a. Economic growth. Following most of the papers, we use the annual real growth of per capita GDP as one of our endogenous variables in the analysis, which approximates the degree of the countries economic development.

b. Oil dependence. We use the following three alternative endogenous variables (for robustness purposes) as proxies of oil dependence: (i) oil share as a percentage of GDP, (ii) oil rents as a percentage of GDP and (iii) oil revenues per capita. The choice of these proxies are in line with Arezki and Brückner (2011), Bjorvatn et al. (2012) and Apergis and Payne (2014). We interpret these variables as a measure of the oil dependence, rather than as a measure of oil abundance, which could be better proxied by a stock measure (see, for instance, Brunnschweiler and Bulte, 2008 , for a discussion of the differences between resource abundance, resource rents and resource dependence). Since the oil shares and the oil rents are divided by the size of the economy, this ratio will not be independent of the economic policies carried out by each of the countries, and thus, this variable should be treated as endogenous.

c. Quality of political institutions. Again, for robustness purposes, we use two alternative measures of political institutional quality: (i) Polity IV index from the Polity IV project (Marshall Monty et al., 2009) and (ii) Political Rights index (from the Freedom House). The Polity IV index is a commonly used proxy for institutional quality in several studies (see, for example Bhattacharyya and Hodler, 2010; Arezki and Brückner, 2011; Bjorvatn et al., 2012; Brückner et al., 2012; El Anshasy and Katsaiti, 2013; Boschini et al., 2013; Caselli and Tesei, 2016). The Political Rights index also approximates the quality of institutions, although it is constructed based on the responses to different questions related to the electoral process, political pluralism and participation and functioning of government, and it has also been used in the literature (see, e.g., Arezki and Brückner, 2011).

d. Interaction term. Economic and political science literature tend to include an interactive term between the quality of institutions and natural resource abundance or share. In our case, we use an interaction term between the oil dependence and the constraints to the executives, 
so as to account for the interdependencies among the quality of political institutions, economic growth and oil abundance. This interaction term is the third dependent/endogenous variable that we use in the extended PVAR model.

e. Exogenous control variables. In order to avoid any potential omitted variable bias, we also control for several exogenous variables typically used in the endogenous growth theory, namely, labour force participation, gross fixed capital formation and openness.

\subsection{PVAR}

This paper uses data from 76 economies for the period 1980-2012. The PVAR methodology we employ, originally developed by Holtz-Eakin et al. (1988), extends the traditional VAR model introduced by Sims (1980), which treats all the variables in the system as endogenous, with the panel-data approach, which allows for unobserved individual heterogeneity. In its general form, the PVAR model can be expressed as follows:

$$
Y_{i t}=A_{0}+A_{1} Y_{i t-1}+A_{2} Y_{i t-2}+\ldots+A_{j} Y_{i t-j}+B X_{i t}+\mu_{i}+\lambda_{t}+\varepsilon_{i t}
$$

where $Y_{i t}$ is a vector of our dependent/endogenous variables, namely real per capita economic growth and oil dependence (proxied by either oil share as a \% of GDP, oil rents or oil revenue per capita). The autoregressive structure allows all endogenous variables to enter the model with a number of $j$ lags. $X_{i t}$ is a vector of the exogenous variables (commonly used in endogenous growth models) comprising: (i) gross fixed capital formation as a \% of GDP, measuring capital input, (ii) imports plus exports as a \% of GDP, capturing the degree of openness, and (iii) labour force participation, capturing human capital. $\mu_{i}$ accounts for the unobservable country characteristics (country fixed-effects) and $\lambda_{t}$ accounts for any global shocks that may affect all countries in the same way (time fixed-effects). Finally, $\varepsilon_{i t}$ denotes the error term.

As indicated above, our benchmark specification is a PVAR that contains the real per capita GDP growth rate and a proxy of oil dependence, as well as exogenous variables and countryand time-fixed-effects, for the full sample. However, we also estimate the same model using only autocratic countries, so as to discover if the quality of political institutions impacts on the oil dependence-economic growth relationship. Furthermore, we extend the benchmark model to a PVAR with the inclusion of an additional dependent/endogenous variable that captures the effects of the constraints to the executives on the resource curse hypothesis. More specifically, we use an interaction term between oil dependence and the 'Regulation of Chief Executive Recruitment' (INTER_1; as defined in Table 2). Thus, we allow for all these variables to be 
endogenous, addressing one of the main empirical problems of the related literature.

In fact, as a first step, and in order to justify the methodology used in this paper, we pursued Block exogeneity tests, as a test for the endogeneity/exogeneity of the key variables in the study. A variable is said to Granger cause another variable if there is enough evidence to reject the null hypothesis that the coefficients on the lags of the vector of variables $Y_{k t-j}$ in the PVAR equation of $Y_{i t}$, where $i \neq k$, are all equal to zero. The results of this test reported in Table 3 , provide evidence of causality among the three variables (i.e., economic growth, oil dependence and quality of institutions), suggesting that these variables should be treated as endogenous. ${ }^{7}$ This is the approach that we follow in this study.

[Insert Table 3 about here]

In order to get a more complete picture of the dynamic interactions among oil dependence, economic growth and political institutions, we perform a panel generalised impulse-response function (PGIRF) analysis, in order to assess the speed of adjustments to shocks originating in our aforementioned variables. The panel generalised impulse response function analysis employed, which is based on Koop et al. (1996) and Pesaran and Shin (1998), provides a natural solution when theory does not provide a clear cut guidance on the ordering of the aforementioned endogenous variables, as in our case. Moreover, the PGIRFs are also decomposed into the responses of shocks to specific variables by taking out from the PGIRFs the effects of shocks to all other variables (Koop et al., 1996), which gives us further insights into the mechanisms at work.

\section{Empirical results}

\subsection{Descriptive statistics and causality tests}

In Table 4, we present the descriptive statistics of our main variables for the full data sample (i.e., 76 countries between 1980 and 2012). It is evident from this table that, real GDP per capita growth averaged at $1.67 \%$ and the oil abundance variables averaged between $8.40 \%-10.09 \%$. Compared to real GDP per capita growth, the oil abundance variables are more volatile. On average, the countries in the sample are characterised by high degree of openness $(72.04 \%)$, abundant human capital $(59.87 \%)$ and moderate capital input (21.91\%). According to the

\footnotetext{
${ }^{7}$ The Granger-causality results for the subsample groups, which are qualitatively similar, are available from the authors upon request.
} 
panel unit root test, all series are stationary, indicating the appropriateness of using them in the PVAR analysis. ${ }^{8}$

[Insert Table 4 about here]

\subsection{Panel Generalised Impulse Response Functions: Full sample analysis}

Based on the estimation of Equation (1), with a lag order of 4 determined by the Akaike Information Criterion (AIC) and Schwarz Bayesian Criterion (SBC), we first calculate the generalised panel impulse response functions tracing out the reaction of real per capita GDP growth to a shock on oil share and vice versa. ${ }^{9}$

For brevity, we report only the PGIRFs, where a positive (negative) response of one variable to a positive shock of another variable is depicted by a response line above (below) zero. The two dashed lines (above and below the solid response line) show the 95\% confidence intervals.

Figure 1 (Panel A) depicts the dynamic path of adjustment to a shock on oil share in year 1 and in subsequent periods (up to 15 years) based on a PVAR model with only these two endogenous variables, as well as the exogenous variables (i.e., labour force participation, openness and gross fixed capital formation).

[Insert Figure 1 about here]

Our results indicate that oil share tends to have a positive effect on per capita real GDP growth in the long-run (up to 15 years). Furthermore, we observe that a positive shock to the per capita real GDP growth triggers a positive response from the oil share, yet only short-lived (up to 2 years), as it becomes insignificant thereafter. This is suggestive of the fact that, based on the full sample estimation, higher levels of oil share lead to higher economic growth, contrary to the empirical evidence of the resource curse hypothesis (as in Raddatz, 2007; Alexeev and Conrad, 2009; Brunnschweiler and Bulte, 2008). In addition, we report for the first time that there is a feedback mechanism from economic growth to the oil share, which might suggest that economic growth could lead to better exploitation of oil resources and thus increase the oil share for a country, which points again to the endogeneity of the oil abundance variables in this type of studies (Collier and Goderis, 2012).

\footnotetext{
${ }^{8}$ The results for the subgroups of countries and proxies of oil abundance and institutional quality, point towards similar conclusions. Thus, for the sake of brevity, these are not presented but are available upon request from the authors.

${ }^{9}$ Post-PVARs estimation of misspecification tests reveal no evidence of residual autocorrelation and heteroscedasticity. In addition, the stability conditions are satisfied. These results are available upon request from the authors.
} 
In order to analyse the role of the institutions, we estimate the previous PVAR model distinguishing between democratic and autocratic countries and the results are displayed in Panel B of Figure 1. Interestingly enough, the response of per capita real GDP growth to a positive shock to oil share, considering only the autocracies, is still positive, however, only in the short-run. In addition, the magnitude of the response is lower compared to the PGRIFS when all countries are considered (Panel A). This fact suggests that oil share has a higher positive effect on economic growth in democratic rather than in autocratic countries. Similarly, a positive shock to economic growth is not translated into a positive response from the oil share of the autocracies, as evident by the insignificant response of INTER_1 to a per capita real GDP growth shock. Even though we do not report a negative relationship between oil share and economic growth for the non-democratic countries (as in Sachs and Warner, 1999, 2001; Gylfason et al., 1999; Rodriguez and Sachs, 1999), this finding allows us to confirm the resource curse hypothesis and the role of the institutions in explaining the oil dependence and economic growth relationship (as in Isham et al., 2005; Mehlum et al., 2006a,b). Although the findings for the resource curse hypothesis have been previously reported, we also show for the first time that the reverse causality is still evident, yet only for democracies. Thus, the role of institutions in explaining the positive significant relationship from economic growth to oil rents adds a new channel through which institutions should be considered when analysing the resource curse hypothesis.

Next, we assess whether the results are different when we take into consideration the degree of constraints on the executive (as approximated by the xrreg variable; as defined in Table 2). As aforementioned, this is a rather important innovation of this study, as constraints to the executives could "force" an autocratic regime to exhibit democratic traits.

To capture the effects of these constraints we employ our interaction term (INTER_1; as defined in Table 2). The results are reported in Panel $\mathrm{C}$ of Figure 1. We notice, that the response of the economic growth to a positive shock to oil share, given an autocracy with high constraints on the executive (INTER_1), is of higher magnitude compared to the response in Panel B. However, the effect is of lower magnitude (and limited to a shorter time period) than the obtained in Panel A, suggesting again that the positive relationship between oil share and economic growth is higher for democratic countries and countries with constraints to the executive. This result justifies again the inclusion of quality of institutions as a channel through which oil rents may influence economic growth (Mehlum et al., 2006a,b). In addition, the oil share for those autocracies with high constraints to the executive responds positively (although 
only in the short-run) to an economic shock, as evident by the right PGIRF of Panel C.

\subsection{Panel Generalised Impulse Response Functions: Subgroup analysis}

In this section we analyse the robustness of our results by means of estimating previous specifications of the PVAR for different subgroups of countries (as classified in Table 1).

First, we estimate the PVAR model for developing and developed countries, and display the results in Figures 2 and 3, respectively. As shown in the Panels A of Figures 2 and 3, oil share leads to higher growth in both developing and developed countries, although this effect is of a lower magnitude for the developed countries (see left PGIRFs of Panels A of Figures 2 and 3). This is rather expected given that the oil sector in the developed countries may not be a key sector for the economic, whereas the reverse is true for the developing economics. Indicatively, the oil revenues in Venezuela account for about $25 \%$ of the countrys GDP and $95 \%$ of its exports, whereas for the UK, the same ratios are about 1.2

\section{[Insert Figure 2 about here]}

[Insert Figure 3 about here]

Again, when we focus only on the autocratic countries we find that oil share does not have any effect on the economic growth of autocracies in developing countries (see left PGIRF in Panel B of Figure 2), however; a short-run positive response is evident for the autocratic developed countries (see left PGIRF in Panel B of Figure 3). In addition, we observe no significant response from the oil share in the autocratic developing countries to positive economic shocks, whereas a marginal and extremely short-run positive response is observed for the autocratic developed economies (see right PGIRFS in Panels $\mathrm{C}$ of Figures 2 and 3). Once again when we consider the constraints to the executives (see Panels C of Figures 2 and 3) we observe for the case of the autocratic developing economies that there is indeed a positive response of the economic growth to a positive shock of the oil share. Thus, we show again that in the case developing economies with autocratic regimes and low constraints to the executives the resource curve is evident. We should highlight here again that it is important to consider the constraints to the executives in this line of research, as simply distinguishing between autocratic and democratic regimes, does not reveal the full dynamics of the relationship between oil dependence and economic growth.

Finally, we control for the income group (low/medium-low, medium-high and high income countries) when analysing the resource curse hypothesis. The results are shown in Figures 4, 5 and 6 . 
[Insert Figure 4 about here]

[Insert Figure 5 about here]

[Insert Figure 6 about here]

We find evidence of heterogeneous responses among the different income groups. In particular, there is no significant relationship between oil share and economic growth in the low/mediumlow income group and this finding is robust even when we consider only the autocratic countries or the interaction term (see Figure 4).

Turning to the medium-high income group of countries we document that the positive long run effects of oil share are mainly driven by democratic countries (left PGIRFs in Panels A and $\mathrm{B}$ in Figure 5) or by autocracies that have in place significant constraints to the executive (see left PGIRF in Panel C of Figure 5). The reverse causality (i.e. from the economic growth to oil share) does not exist for this income group.

More importantly, we find bidirectional relationship between oil share and economic growth for the high-income countries group, although these effects are short-lived. This finding holds true for all specifications (see PGIRFs of Figure 6.

Overall, our results suggest that controlling for the quality of political institutions, and more importantly the constraints to the executives is important in rendering the resource curse hypothesis significant. Doing so, the resource curse hypothesis is documented mainly for developing economies and medium-high income countries. Specifically, when economies from the aforementioned groups are characterised by weak quality of political institutions (autocracies with limited constraints to the executive), oil dependence is not growth-enhancing. This might suggest that these autocrats or the political elite exploit the benefits of the country's oil resources to accommodate their own rent-seeking behaviour, without considering the potential positive long-run benefits to the wider economy. ${ }^{10}$ Gylfason (2001), for example, argues that nations that consider their natural resources to be their most important asset may neglect the development of other resources, such as education. However, the existence of high-quality institutions (those able to create positive incentives for entrepreneurial growth) is crucial to translate the benefits from oil to productive activities (Mehlum et al., 2006a,b).

\footnotetext{
${ }^{10}$ Last but not least, our main results are robust to different proxies of oil dependence, economic growth (growth rates, GDP per capita growth, 5-year period growth rates) and quality of political institutions (polity index and the freedom house political rights index). For the sake of brevity we do not report these results, which are, however, available upon request from the authors.
} 


\section{Conclusions}

In this paper we shed more light to the contested literature on the resource curse hypothesis, by estimating a PVAR approach along with PGIRFs to data on oil dependence, economic growth and several political institutional variables for 76 countries grouped under different income groupings and level of development, over the period 1980-2012. To our knowledge, this is the first paper that adopts a PVAR and PGIRFs analyses, to study the impact of oil dependence on economic growth taking into account the endogeneity of institutional quality, as well as controlling for commonly used indicators in the growth literature in order to shed more light into the natural resource curse hypothesis. The use of this methodology allow us to control for cross-country unobservable heterogeneity, account for time fixed-effects, analyse the dynamic relationship between the different variables, and most importantly, to address the endogeneity problem often found in these type of studies. Furthermore, it is the first study to consider how the constraints to the executives could influence the relationship between oil dependence and economic growth.

The results of our empirical analysis reveal the following regularities. First, we document the need of considering per capita real GDP growth, oil dependence and quality institutions as endogenous variables, which justifies the use of panel VAR models in analyzing the relationship between these variables. Second, we find significant evidence that positive oil share shocks are growth-enhancing, when we do not account for institutional quality, suggesting thus, evidence against the resource curse hypothesis in that case. Third, controlling for the quality of political institutions seems important in rendering the resource curse hypothesis significant. Doing so, the resource curse hypothesis is documented mainly for developing economies and medium-high income countries. Specifically, when economies from the aforementioned groups are characterised by weak quality of political institutions, then oil dependence is not growth-enhancing.

These results are robust to different proxies of oil dependence, economic growth (overall GDP growth, 5-year period growth rates) and quality of political institutions (polity index and the freedom house political rights index).

Overall, our findings, based on the suggested dynamic approach that deals with a number of issues in the estimation process, provide new insights in the resource curse hypothesis. Moreover, our analysis shows that the resource curse hypothesis is mainly driven by the quality of political institutions, but more importantly, the constraints imposed to the executives. This suggests that the natural resource hypothesis hold true for autocracies with limited constraints to the 
executive.

\section{References}

Acemoglu, D., Johnson, S., Robinson, J. A., 2001. The colonial origins of comparative development: An empirical investigation. The American Economic Review 91 (5), 1369-1401.

Acemoglu, D., Johnson, S., Robinson, J. A., 2002. Reversal of fortune: Geography and institutions in the making of the modern world income distribution. The Quarterly Journal of Economics 117 (4), 1231-1294.

Acemoglu, D., Johnson, S., Robinson, J. A., Yared, P., 2008. Income and democracy. The American Economic Review, 808-842.

Alexeev, M., Conrad, R., 2009. The elusive curse of oil. The Review of Economics and Statistics $91(3), 586-598$.

Andersen, J. J., Aslaksen, S., 2008. Constitutions and the resource curse. Journal of Development Economics 87 (2), 227-246.

Apergis, N., Payne, J. E., 2014. The oil curse, institutional quality, and growth in MENA countries: Evidence from time-varying cointegration. Energy Economics 46, 1-9.

Arezki, R., Brückner, M., 2011. Oil rents, corruption, and state stability: Evidence from panel data regressions. European Economic Review 55 (7), 955-963.

Auty, R., 2002. Sustaining development in mineral economies: The resource curse thesis. Routledge.

Barro, R. J., 1999. Determinants of democracy. Journal of Political Economy 107 (S6), S158S183.

Bhattacharyya, S., Hodler, R., 2010. Natural resources, democracy and corruption. European Economic Review 54 (4), 608-621.

Bjorvatn, K., Farzanegan, M. R., Schneider, F., 2012. Resource curse and power balance: Evidence from oil-rich countries. World Development 40 (7), 1308-1316.

Boschini, A., Pettersson, J., Roine, J., 2013. The resource curse and its potential reversal. World Development 43, 19-41.

Boyce, J. R., Emery, J. H., 2011. Is a negative correlation between resource abundance and growth sufficient evidence that there is a resource curse? Resources Policy 36 (1), 1-13.

Brückner, M., 2010. Natural resource dependence, non-tradables, and economic growth. Journal of Comparative Economics 38 (4), 461-471. 
Brückner, M., Ciccone, A., Tesei, A., 2012. Oil price shocks, income, and democracy. Review of Economics and Statistics 94 (2), 389-399.

Brunnschweiler, C. N., Bulte, E. H., 2008. The resource curse revisited and revised: A tale of paradoxes and red herrings. Journal of Environmental Economics and Management 55 (3), $248-264$.

Busse, M., Gröning, S., 2013. The resource curse revisited: governance and natural resources. Public Choice 154 (1-2), 1-20.

Caselli, F., Tesei, A., 2016. Resource windfalls, political regimes, and political stability. Review of Economics and Statistics, forthcoming.

Cavalcanti, T. V. d. V., Mohaddes, K., Raissi, M., 2011. Growth, development and natural resources: New evidence using a heterogeneous panel analysis. The Quarterly Review of Economics and Finance 51 (4), 305-318.

Collier, P., Goderis, B., 2012. Commodity prices and growth: An empirical investigation. European Economic Review 56 (6), 1241-1260.

Cotet, A. M., Tsui, K. K., 2013. Oil and conflict: What does the cross country evidence really show? American Economic Journal: Macroeconomics 5 (1), 49-80.

El Anshasy, A. A., Katsaiti, M.-S., 2013. Natural resources and fiscal performance: Does good governance matter? Journal of Macroeconomics 37, 285-298.

Epstein, D. L., Bates, R., Goldstone, J., Kristensen, I., O'Halloran, S., 2006. Democratic transitions. American Journal of Political Science 50 (3), 551-569.

Frankel, J. A., 2010. The natural resource curse: A survey. Tech. rep., National Bureau of Economic Research.

Gelb, A. H., 1988. Oil windfalls: Blessing or curse? Oxford University Press.

Glaeser, E. L., Ponzetto, G. A., Shleifer, A., 2007. Why does democracy need education? Journal of Economic Growth 12 (2), 77-99.

Gylfason, T., 2001. Natural resources, education, and economic development. European Economic Review 45 (4), 847-859.

Gylfason, T., Herbertsson, T. T., Zoega, G., 1999. A mixed blessing. Macroeconomic Dynamics 3 (02), 204-225.

Hadiz, V., Robison, R., 2005. Neo-liberal reforms and illiberal consolidations: The indonesian paradox. The Journal of Development Studies 41 (2), 220-241.

Hodler, R., 2006. The curse of natural resources in fractionalized countries. European Economic 
Review 50 (6), 1367-1386.

Holtz-Eakin, D., Newey, W., Rosen, H. S., 1988. Estimating vector autoregressions with panel data. Econometrica, 1371-1395.

IEA, 2015. 2015 Key World Energy Statistics. International Energy Agency.

Isham, J., Woolcock, M., Pritchett, L., Busby, G., 2005. The varieties of resource experience: natural resource export structures and the political economy of economic growth. The World Bank Economic Review 19 (2), 141-174.

Koop, G., Pesaran, M. H., Potter, S. M., 1996. Impulse response analysis in nonlinear multivariate models. Journal of Econometrics 74 (1), 119-147.

Lederman, D., Maloney, W. F., 2003. Trade structure and growth. World Bank Policy Research Working Paper (3025).

Maloney, W., Lederman, D., 2008. In search of the missing resource curse. Journal of the Latin American and Caribbean Economic Association 29 (1), 1-20.

Marshall Monty, G., Jaggers, K., Gurr, T. R., 2009. Polity IV Project: Political regime characteristics and transitions, 1800-2009. Dataset Users Manual. Center for International Development and Conflict Management, University of Maryland.

Mehlum, H., Moene, K., Torvik, R., 2006a. Cursed by resources or institutions? The World Economy 29 (8), 1117-1131.

Mehlum, H., Moene, K., Torvik, R., 2006b. Institutions and the resource curse*. The Economic Journal 116 (508), 1-20.

Papaioannou, E., Siourounis, G., 2008. Democratisation and growth. The Economic Journal 118 (532), 1520-1551.

Papyrakis, E., Gerlagh, R., 2004. The resource curse hypothesis and its transmission channels. Journal of Comparative Economics 32 (1), 181-193.

Pesaran, H. H., Shin, Y., 1998. Generalized impulse response analysis in linear multivariate models. Economics Letters 58 (1), 17-29.

Raddatz, C., 2007. Are external shocks responsible for the instability of output in low-income countries? Journal of Development Economics 84 (1), 155-187.

Rodriguez, F., Sachs, J. D., 1999. Why do resource-abundant economies grow more slowly? Journal of Economic Growth 4 (3), 277-303.

Ross, M. L., 2001. Does oil hinder democracy? World politics 53 (3), 325-361.

Sachs, J. D., Warner, A. M., 1995. Natural resource abundance and economic growth. NBER 
Working Papers 5398, National Bureau of Economic Research, Inc.

Sachs, J. D., Warner, A. M., 1999. The big push, natural resource booms and growth. Journal of Development Economics 59 (1), 43-76.

Sachs, J. D., Warner, A. M., 2001. The curse of natural resources. European Economic Review $45(4), 827-838$.

Sala-i Martin, X., Subramanian, A., 2013. Addressing the natural resource curse: An illustration from Nigeria. Journal of African Economies 22 (4), 570-615.

Sims, C. A., 1980. Macroeconomics and reality. Econometrica 48 (1), 1-48.

van der Ploeg, F., 2011. Natural resources: Curse or blessing? Journal of Economic Literature 49 (1), 366-420.

van der Ploeg, F., Poelhekke, S., 2010. The pungent smell of red herrings: Subsoil assets, rents, volatility and the resource curse. Journal of Environmental Economics and Management $60(1), 44-55$.

Yaduma, N., Kortelainen, M., Wossink, A., et al., 2013. An investigation of oil curse in OECD and Non-OECD oil exporting economies using green measures of income. Economics Discussion Paper Series EDP-1321, The Manchester University. 
Table 1: Countries included in the sample

\begin{tabular}{|c|c|c|c|}
\hline \multicolumn{4}{|c|}{ Panel A: Income Groups } \\
\hline \multicolumn{4}{|c|}{ Low and Medium-Low Income } \\
\hline Bangladesh & Bolivia & Cameroon & Congo Brazzaville \\
\hline Congo (Dem Rep) & Egypt & Ghana & Guatemala \\
\hline India & Indonesia & Nigeria & Pakistan \\
\hline Paraguay & Philippines & Syria & Vietnam \\
\hline Yemen & & & \\
\hline \multicolumn{4}{|c|}{ Medium-High Income } \\
\hline Albania & Algeria & Angola & Argentina \\
\hline Bulgaria & China & Colombia & Cuba \\
\hline Dominican Rep & Ecuador & Gabon & Hungary \\
\hline Iran & Iraq & Jordan & Libya \\
\hline Malaysia & Mexico & Peru & Romania \\
\hline Thailand & Trinidad and Tobago & Tunisia & Turkey \\
\hline Venezuela & & & \\
\hline \multicolumn{4}{|c|}{ High Income } \\
\hline Australia & Austria & Bahrain & Belgium \\
\hline Brazil & Canada & Chile & Denmark \\
\hline Finland & France & Germany & Greece \\
\hline Ireland & Israel & Italy & Japan \\
\hline Kuwait & New Zealand & Norway & Netherlands \\
\hline Oman & Poland & Portugal & Qatar \\
\hline Korea South & Russia & Saudi Arabia & Singapore \\
\hline Spain & Sweden & Switzerland & United Arab Emirates \\
\hline United Kingdom & United States & & \\
\hline \multicolumn{4}{|c|}{ Panel B: Level of Development } \\
\hline \multicolumn{4}{|c|}{ Developed } \\
\hline Australia & Austria & Bahrain & Belgium \\
\hline Canada & Chile & Denmark & Finland \\
\hline France & Germany & Greece & Ireland \\
\hline Israel & Italy & Japan & Kuwait \\
\hline New Zealand & Norway & Netherlands & Oman \\
\hline Poland & Portugal & Qatar & Korea South \\
\hline Russia & Saudi Arabia & Singapore & Spain \\
\hline Sweden & Switzerland & Trinidad and Tobago & United Arab Emirates \\
\hline United Kingdom & United States & & \\
\hline \multicolumn{4}{|c|}{ Developing } \\
\hline Albania & Algeria & Angola & Argentina \\
\hline Bangladesh & Bolivia & Brazil & Bulgaria \\
\hline Cameroon & China & Colombia & Congo Brazzaville \\
\hline Congo (Dem Rep) & Cuba & Dominican Rep & Ecuador \\
\hline Egypt & Gabon & Ghana & Guatemala \\
\hline Hungary & India & Indonesia & Iran \\
\hline Iraq & Jordan & Libya & Malaysia \\
\hline Mexico & Nigeria & Pakistan & Paraguay \\
\hline Peru & Philippines & Romania & Syria \\
\hline Thailand & Tunisia & Turkey & Venezuela \\
\hline Vietnam & Yemen & & \\
\hline
\end{tabular}


Table 1: Countries included in the sample (cont.)

\begin{tabular}{|c|c|c|c|}
\hline \multicolumn{4}{|c|}{ Panel C: Level of Democracy } \\
\hline \multicolumn{4}{|c|}{ Democracies } \\
\hline Albania & Algeria & Argentina & Australia \\
\hline Austria & Belgium & Bangladesh & Bolivia \\
\hline Brazil & Bulgaria & Canada & Chile \\
\hline Colombia & Congo (Dem Rep) & Denmark & Dominican Rep \\
\hline Ecuador & Finland & France & Gabon \\
\hline Germany & Ghana & Greece & Guatemala \\
\hline Hungary & India & Indonesia & Ireland \\
\hline Iraq & Israel & Italy & Japan \\
\hline Malaysia & Mexico & New Zealand & Nigeria \\
\hline Norway & Netherlands & Pakistan & Paraguay \\
\hline Peru & Philippines & Poland & Portugal \\
\hline Korea South & Romania & Russia & Spain \\
\hline Sweden & Switzerland & Thailand & Trinidad and Tobago \\
\hline Turkey & United Kingdom & United States & \\
\hline \multicolumn{4}{|c|}{ Non-Democracies } \\
\hline Angola & Bahrain & Cameroon & China \\
\hline Congo Brazzaville & Cuba & Egypt & Iran \\
\hline Jordan & Kuwait & Libya & Oman \\
\hline Qatar & Saudi Arabia & Singapore & Syria \\
\hline Tunisia & United Arab Emirates & Venezuela & Vietnam \\
\hline Yemen & & & \\
\hline
\end{tabular}

Note: The income-country groupings, as well as, the grouping between developed and developing are based on the World Bank and United Nations classifications, respectively. 
Table 2: Variable description and sources

\begin{tabular}{|c|c|c|c|}
\hline Name & Description & Source & Notes \\
\hline $\begin{array}{l}\text { Economic } \\
\text { Growth }\end{array}$ & $\begin{array}{l}\text { Growth rate of real per } \\
\text { capita GDP (GDPPCGR) }\end{array}$ & IMF & $\begin{array}{l}\text { Log difference of per capita GDP (in PPP, } \\
\text { constant } 2005 \text { intnl } \$ \text { ) }\end{array}$ \\
\hline Oil rents & Oil rents (as \% of GDP) & World Bank & $\begin{array}{l}\text { Difference between the value of crude oil } \\
\text { production at world prices and total costs } \\
\text { of production }\end{array}$ \\
\hline Oil share & Oil share (as \% of GDP) & IMF, EIA & Value of crude oil exports as \% of GDP. \\
\hline Oil revenue & Oil revenue per capita & IMF, EIA & Value of crude oil exports per capita \\
\hline Polity IV & $\begin{array}{l}\text { Rating based on a }+10 \\
\text { (strongly democratic) to } \\
-10 \text { (strongly autocratic) } \\
\text { scale }\end{array}$ & $\begin{array}{l}\text { Polity IV } \\
\text { project }\end{array}$ & $\begin{array}{l}\text { Substracting the AUTOC score from the } \\
\text { DEMOC score in the Polity IV database }\end{array}$ \\
\hline Xrreg & $\begin{array}{l}\text { Rating based on a } 1 \text { to } 3 \\
\text { scale }\end{array}$ & $\begin{array}{l}\text { Polity IV } \\
\text { project }\end{array}$ & $\begin{array}{l}\text { It is a component of the Polity IV index, and } \\
\text { measures the "Regulation of Chief Executive } \\
\text { Recruitment" mechanism }\end{array}$ \\
\hline $\begin{array}{l}\text { Political } \\
\text { rights }\end{array}$ & $\begin{array}{l}\text { Rating based on a } 1 \text { to } 7 \\
\text { scale }\end{array}$ & $\begin{array}{l}\text { Freedom } \\
\text { House }\end{array}$ & $\begin{array}{l}\text { The ratings process is based on a checklist of } \\
\text { 10political rights questions related to the } \\
\text { electoral process, political pluralism and } \\
\text { participation and functioning of government }\end{array}$ \\
\hline $\begin{array}{l}\text { Democracy } \\
\text { status }\end{array}$ & Dummy variable & $\begin{array}{l}\text { Polity IV } \\
\text { project }\end{array}$ & $\begin{array}{l}\text { Countries are classified according to the } \\
\text { Polity IV index in democracies (Polity IV } \\
\text { scores between } 6 \text { and 10), and anocracies/ } \\
\text { autocracies (Polity IV scores between -10 } \\
\text { and 5) }\end{array}$ \\
\hline $\begin{array}{l}\text { Xrred } \\
\times \\
\text { Oil share }\end{array}$ & $\begin{array}{l}\text { Interactive term } \\
\text { (INTER_1) }\end{array}$ & $\begin{array}{l}\text { IMF, EIA, } \\
\text { Polity IV }\end{array}$ & $\begin{array}{l}\text { Calculated as the product of Xrreg } \\
\text { and Oil share }\end{array}$ \\
\hline Developing & Category & World Bank & $\begin{array}{l}\text { Countries are classified according to their degree } \\
\text { of development, based on World Bank data }\end{array}$ \\
\hline GFCF & $\begin{array}{l}\text { Gross fixed capital } \\
\text { formation }\end{array}$ & World Bank & Expressed as percentage of GDP \\
\hline Trade openness & Trade openness & World Bank & The sum of exports and imports as a percentage of $\mathrm{G}$ \\
\hline LPFR & $\begin{array}{l}\text { Labour force } \\
\text { participation rate }\end{array}$ & World Bank & $\begin{array}{l}\text { Expressed as a percentage of total population of ages } \\
15+\end{array}$ \\
\hline
\end{tabular}

Note: Annual data from 76 countries for the period 1980-2012. 
Table 3: Block exogeneity/Granger-causality tests

\begin{tabular}{llll}
\hline \hline & \multicolumn{3}{c}{ Dependent variable } \\
\hline & $\begin{array}{l}\text { Economic growth } \\
\text { rate }\end{array}$ & Oil share & INTER_1 \\
\cline { 2 - 4 } $\begin{array}{l}\text { Economic growth } \\
\text { rate (excluded) }\end{array}$ & $11.55^{* *}$ & 3.40 \\
Oil share (excluded) & $16.38^{* * *}$ & & \\
INTER_1 (excluded) & $10.04^{* *}$ & 6.19 & $13.55^{* * *}$ \\
All variables & $28.34^{* * *}$ & $17.44^{* *}$ & $15.17^{*}$ \\
\hline \hline
\end{tabular}

Note: The numbers in the table are the Chi-square block exogeneity Wald tests. Under the null hypothesis, the excluded variables do not Granger-cause the dependent variable. ${ }^{*},{ }^{* *}$ and ${ }^{* * *}$ denotes significance at the $10 \%$, $5 \%$ and $1 \%$ level.

Table 4: Descriptive statistics

\begin{tabular}{lllllllll}
\hline \hline & Mean & Minimum & Maximum & Std.Dev. & Skewness & Kurtosis & J-B & LLC \\
\cline { 2 - 8 } GDPPCGR & 1.6688 & -43.0161 & 40.5673 & 4.5809 & -1.2640 & 14.4295 & $13194.21^{*}$ & $-20.93^{*}$ \\
OIL_SHARE & 8.4982 & 0.0000 & 98.8086 & 14.4599 & 3.0219 & 14.0225 & $9685.52^{*}$ & $-28.07^{*}$ \\
OIL_RENT & 10.0863 & 0.0000 & 80.2375 & 14.9963 & 1.8375 & 5.8979 & $1852.66^{*}$ & $-24.53^{*}$ \\
OIL_REVENUE & 8.4171 & 0.0001 & 245.0232 & 20.1332 & 5.8563 & 50.3884 & $154090.8^{*}$ & $-27.17^{*}$ \\
GFCF & 21.9134 & 2.1000 & 59.7324 & 6.1869 & 0.5755 & 5.2960 & $618.13^{*}$ & $-4.80^{*}$ \\
OPENESS & 72.0425 & 6.3203 & 439.6567 & 49.4087 & 3.1378 & 18.3525 & $26877.76^{*}$ & $-39.86^{*}$ \\
LPFR & 59.8670 & 1586.7 & 9.5022 & -0.2659 & 3.3369 & $41.4322^{*}$ & $-5.61^{*}$ & \\
\hline \hline
\end{tabular}

Note: $*$ denotes significance at the $1 \%$ level. J-B denotes the Jarque-Bera test for normality. LLC is the panel unit root test (with just a constant) of Levin, Lin and Chu (2002), which test the null hypothesis of a unit root, against the alternative that the panel is stationary. 
Figure 1: Impulse response functions: Full sample

Panel A: All Countries

Accumulated Response to Generalized One S.D. Innovations \pm 2 S.E.

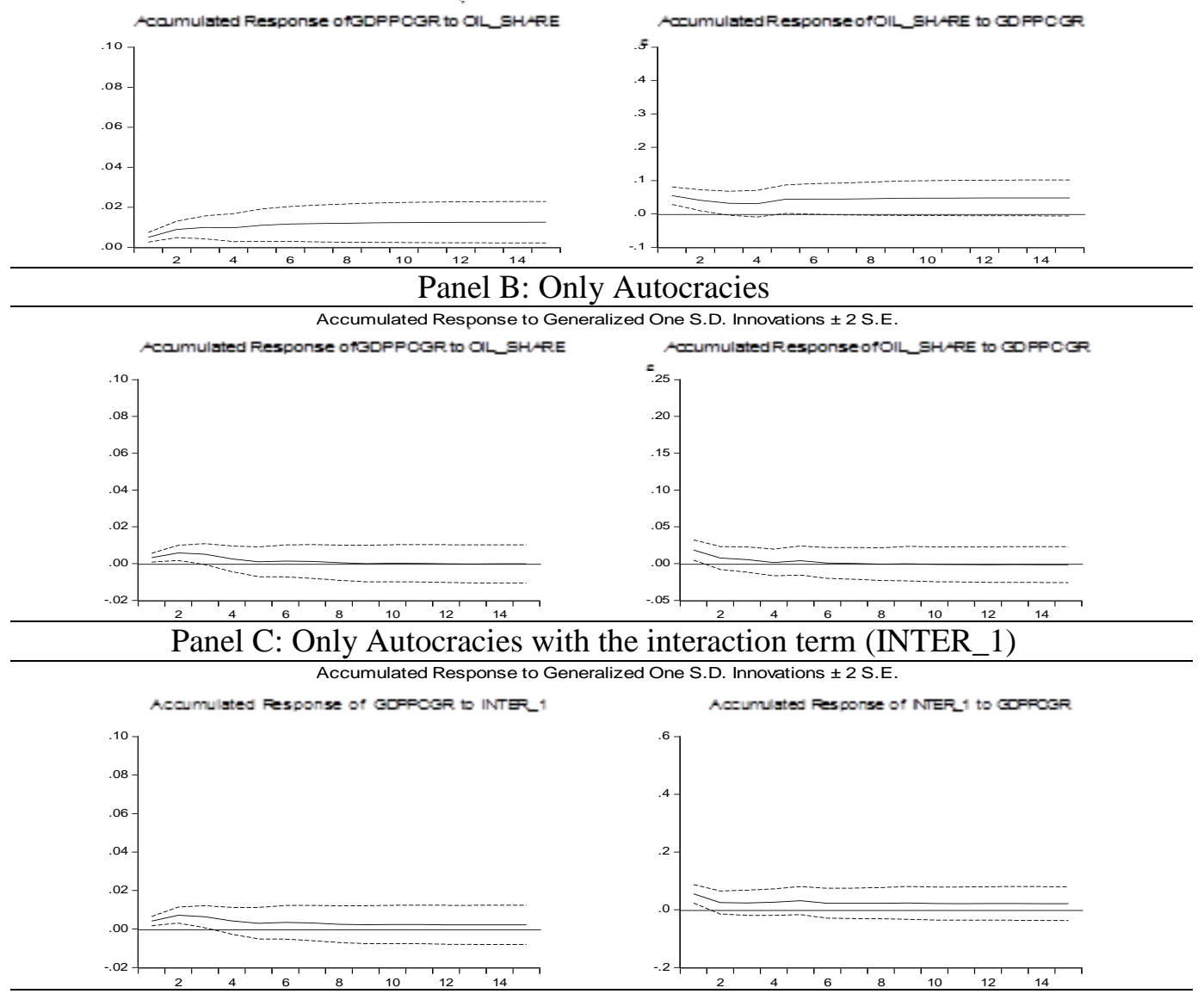


Figure 2: Impulse response functions: Developing

Panel A: All Countries

Accumulated Response to Generalized One S.D. Innovations \pm 2 S.E.

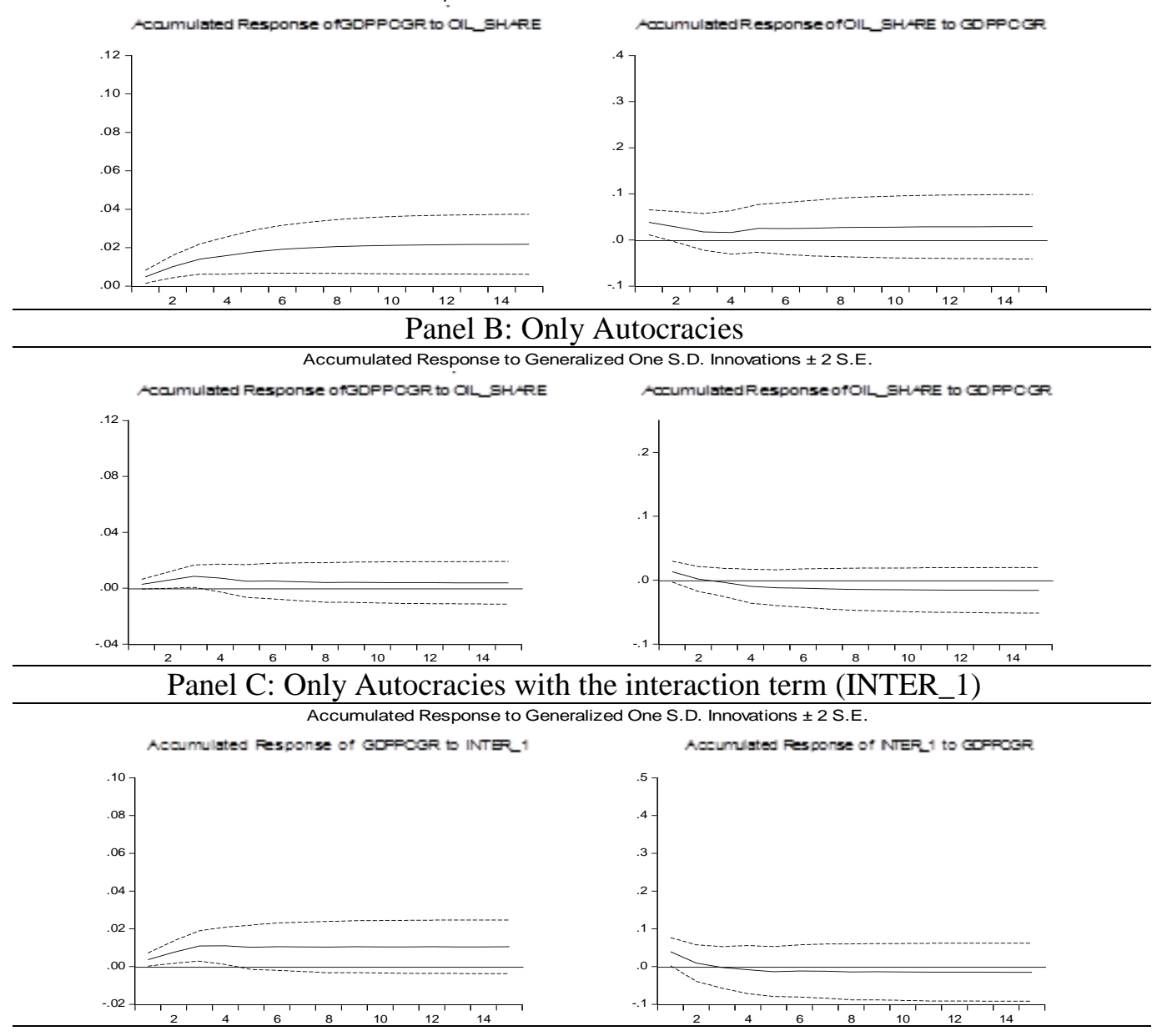


Figure 3: Impulse response functions: Developed Panel A: All Countries

Accumulated Response to Generalized One S.D. Innovations \pm 2 S.E.

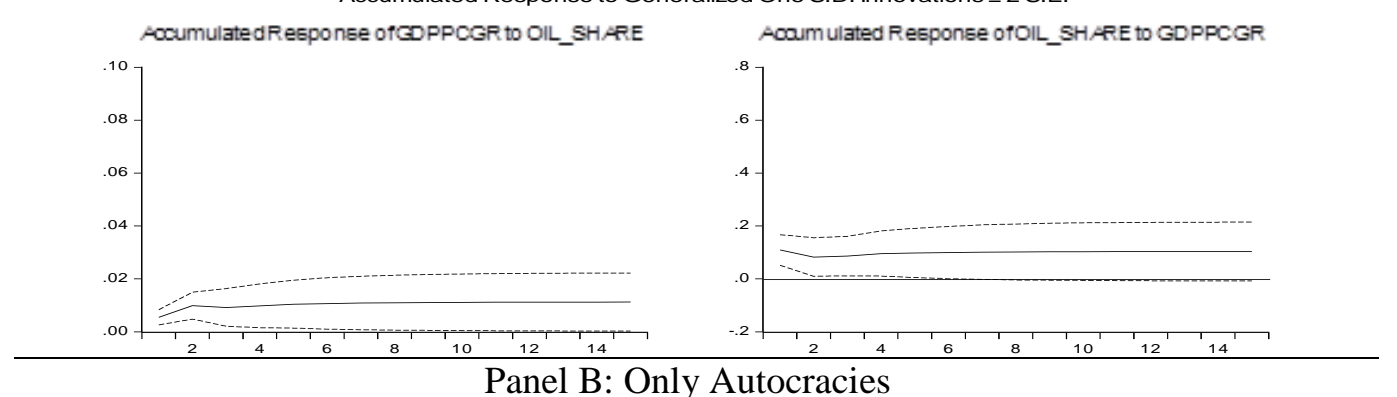

Accumulated Response to Generalized One S.D. Innovations \pm 2 S.E.

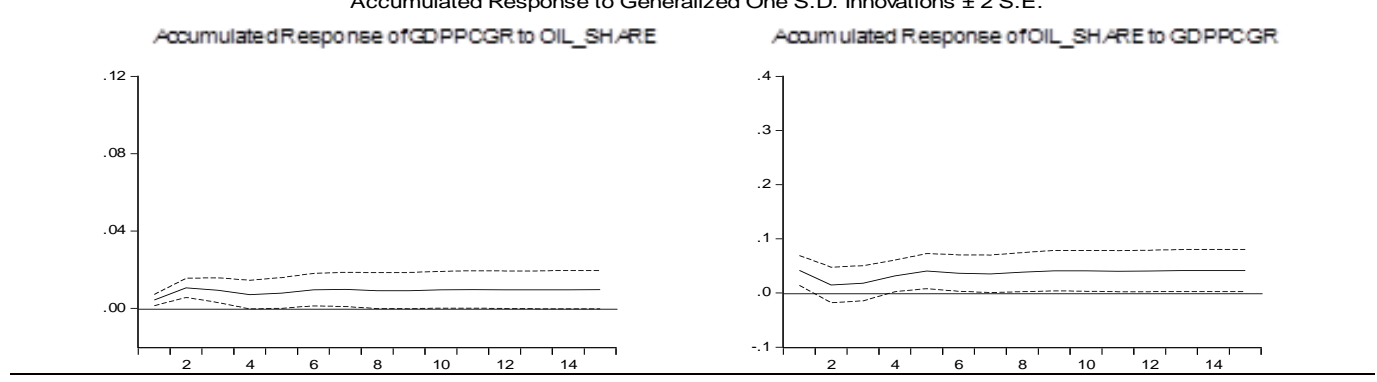

Panel C: Only Autocracies with the interaction term (INTER_1)

Accumulated Response to Generalized One S.D. Innovations \pm 2 S.E. Acoumuted Res pors e of GCPOCSR to NTF_.1

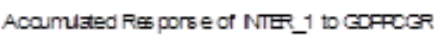
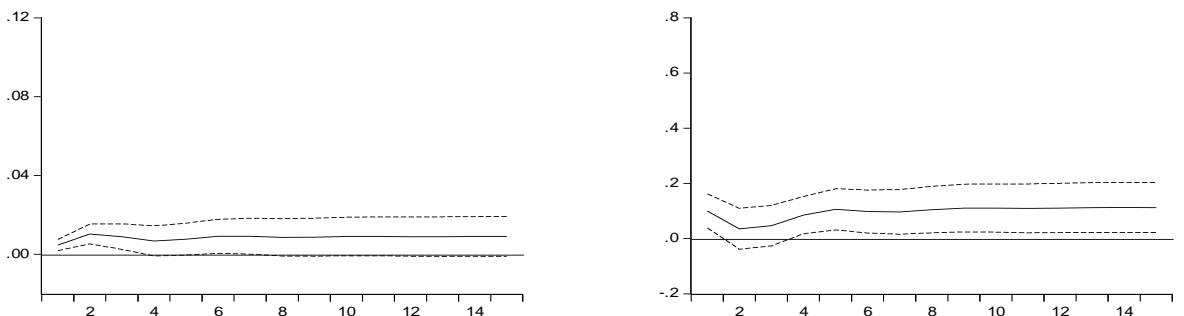
Figure 4: Impulse response functions: Low and Medium-Low Income group Panel A: All Countries

Accumulated Response to Generalized One S.D. Innovations \pm 2 S.E.

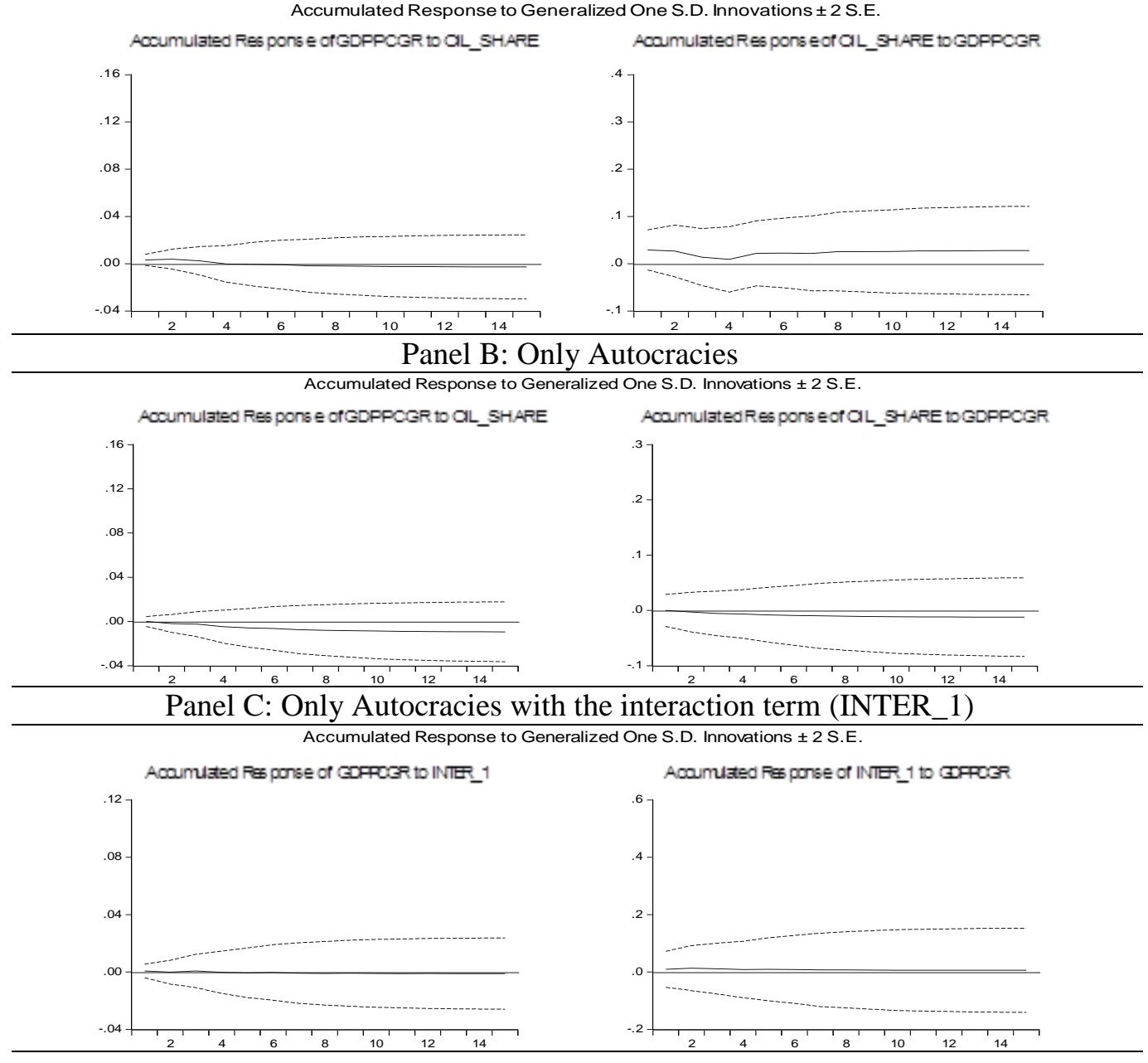


Figure 5: Impulse response functions: Medium-High Income group Panel A: All Countries

Accumulated Response to Generalized One S.D. Innovations \pm 2 S.E.

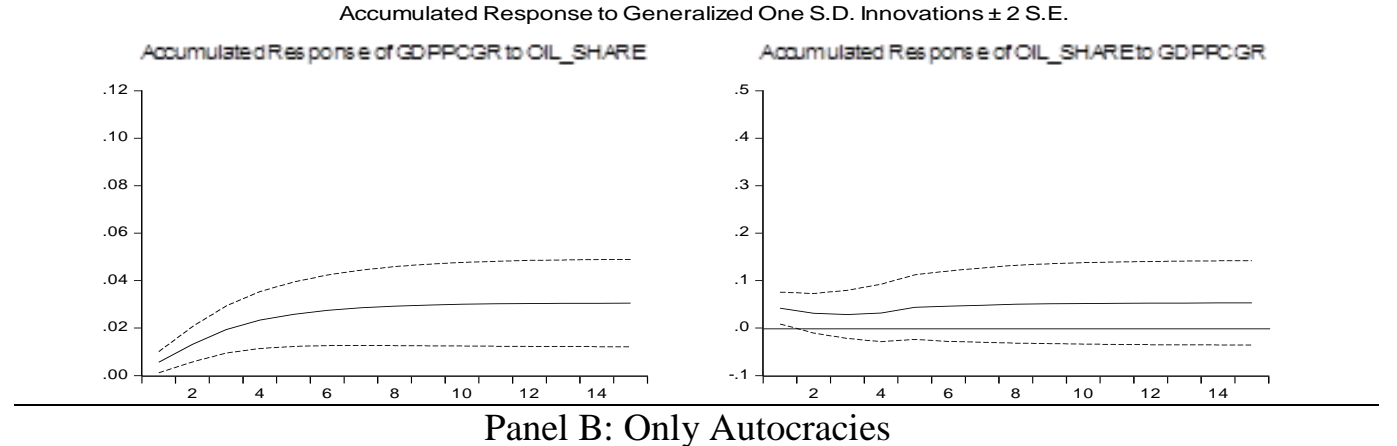

Panel B: Only Autocracies

Accumulated Response to Generalized One S.D. Innovations \pm 2 S.E.

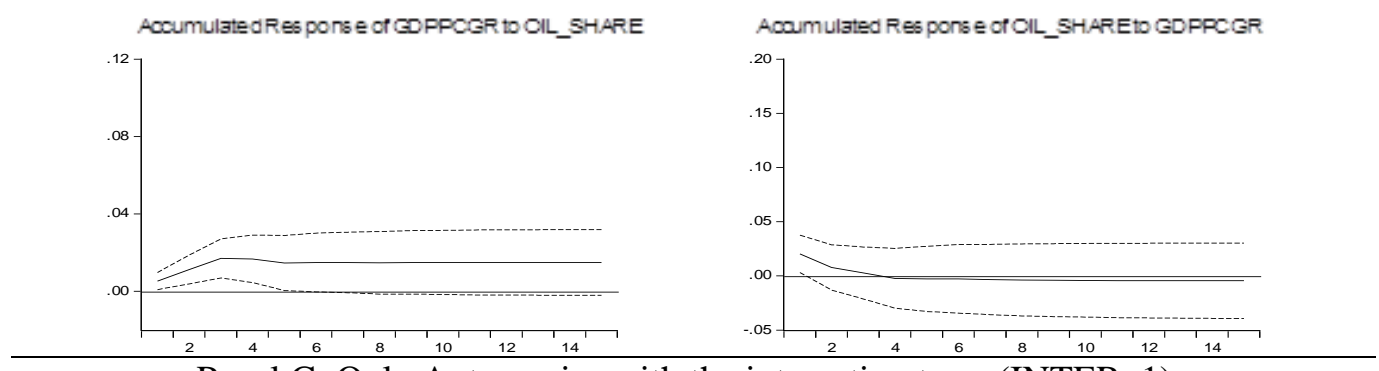

Panel C: Only Autocracies with the interaction term (INTER_1)

Accumulated Response to Generalized One S.D. Innovations \pm 2 S.E.

Accumvited fesponse of GDFPCSR to INITE_-1

Accumulted Fesponse of INITE_-1 to GDFOCBR
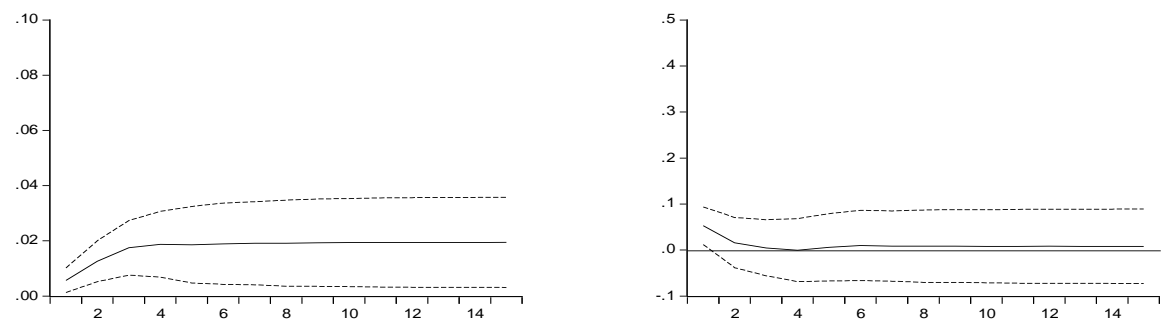
Figure 6: Impulse response functions: High Income group

Panel A: All Countries

Accumulated Response to Generalized One S.D. Innovations \pm 2 S.E.

Acoumulated Res pons e of GDPFCGR to CIL SHARE

ACCumulated Res pons e of CIL_SHARE to GDPPCGR
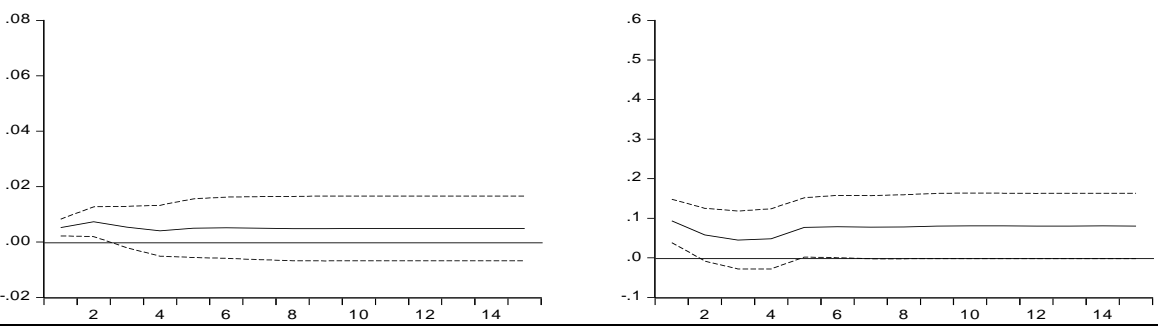

Panel B: Only Autocracies

Accumulated Response to Generalized One S.D. Innovations \pm 2 S.E.

Acoumulated Res pons e ofGDPPCGR to OL_SHARE

Accumulated Res pons e of OL_SHARE to GDPPCGR
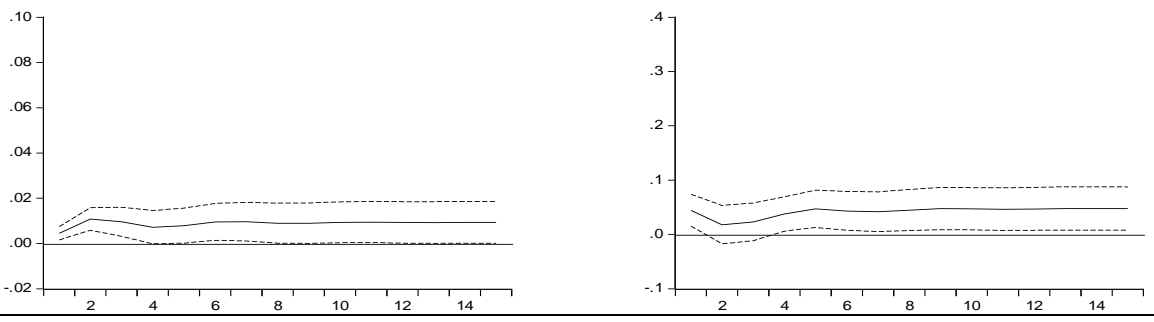

Panel C: Only Autocracies with the interaction term (INTER 1)

Accumulated Response to Generalized One S.D. Innovations \pm 2 S.E.

Accumuzted Fesponse of GCFFCR to INTER 1

Acamulated Fesponse of NItER 1 to GDFPCS
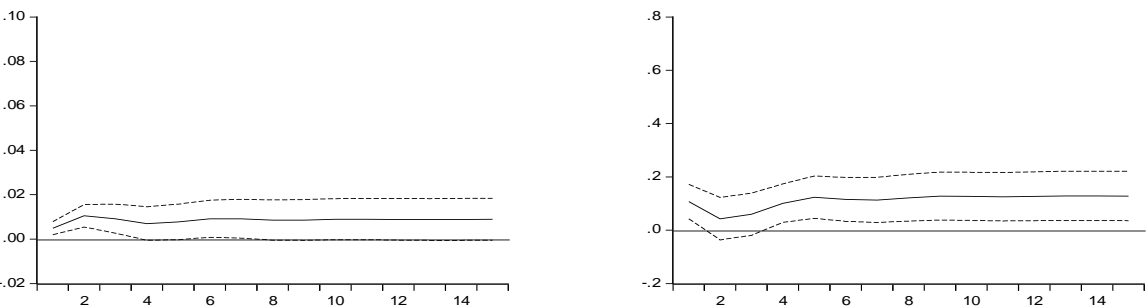